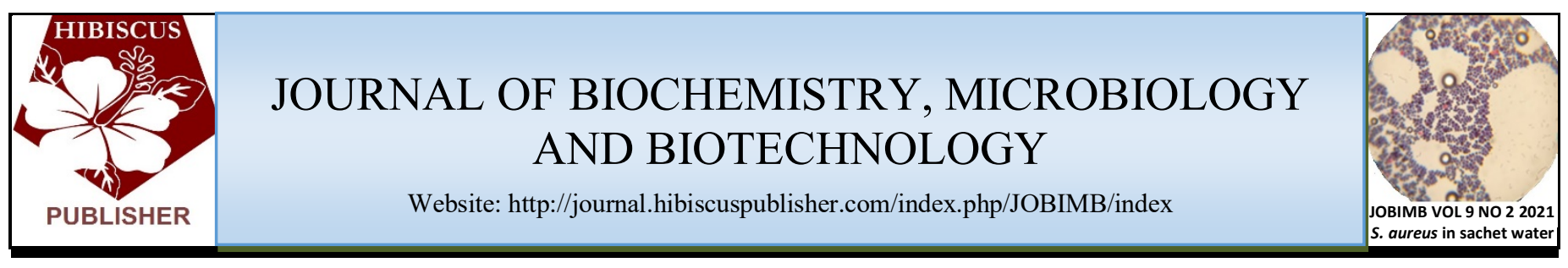

\title{
An Acrylamide-degrading Bacterial Consortium Isolated from Volcanic Soil
}

\author{
Rusnam $^{1 *}$ and Neni Gusmanizar ${ }^{2}$ \\ ${ }^{1}$ Department of Agricultural Engineering, Faculty of Agricultural Technology, Andalas University, \\ Padang, 25163, Indonesia. \\ ${ }^{2}$ Department of Animal Nutrition, Faculty of Animal Science, Andalas University, \\ Padang, 25163, Indonesia. \\ *Corresponding author: \\ Prof Dr. Rusnam, \\ Department of Agricultural Engineering, \\ Faculty of Agricultural Technology, \\ Andalas University, \\ Padang, 25163, \\ Indonesia. \\ Email: rusnam@gmail.com
}

\section{HISTORY}

Received: $14^{\text {th }}$ Sep 2021

Received in revised form: $17^{\text {th }}$ October 2021

Accepted: $23^{\text {rd }}$ Nov 2021

\section{KEYWORDS}

Acrylamide

Acrylamide-degrading

volcanic soils

\begin{abstract}
In soil, polyacrylamide is a key source of acrylamide because it slowly decomposes into acrylamide. There has been a modest but steady rise in worldwide interest in microbe-mediated acrylamide decomposition as a bioremediation method. A bacterial consortium isolated from the volcanic soil of Mount Marapi, West Sumatra, Indonesia, was able to thrive on acrylamide in this study. Acrylamide-degrading bacteria grew best in the presence of $1 \%(\mathrm{w} / \mathrm{v})$ glucose with acrylamide as the sole nitrogen source. Optimum growth occurs in between 300 and $500 \mathrm{mg} / \mathrm{L}$ of acrylamide, $\mathrm{pH}$ between 6.5 and 8.0, and temperatures between 30 and $35^{\circ} \mathrm{C}$. The consortium can also grow on acetamide as the sole nitrogen source. Toxic heavy metals, such as mercury, silver and copper slowed down the growth of this consortium on acrylamide. This is the first report of an acrylamide-degrading consortium isolated from volcanic soils.
\end{abstract}

\section{INTRODUCTION}

Carcinogenic and neurotoxic acrylamide can be formed when high-carbohydrate meals are cooked at a high temperature, a process known as the Maillard reaction. Foods's high in carbohydrate may include acrylamide as a result of the Maillard process. When sugars and amino acids are combined, the Maillard reaction takes place. This is the major process by which acrylamide is formed [1]. On the other hand, acrylamide may be made from other carbonyl compounds [2]. In Sweden and Norway, cows and fish died as a result of acrylamide pollution in neighbouring streams. In the adhesive, plastic, and printing industries, as well as for drinking water treatment (JCPS, 2003), acrylamide is principally used in the production of polyacrylamide (PAM) (JCPS, 2003). In the year 2005, Commercial polyacrylamides are often contaminated by acrylamide's toxic monomer, which has had a significant influence on our food supply chain as a result of their extensive use. Roundup herbicide contains 30 percent polyacrylamide, which pollutes agricultural land with acrylamides. In order to deal with this issue, remediation of acylamide through a biological process is required [3].
Even though acrylamide has been found to cause cancer in experimental animals [4], it is not known if this is the case in humans who are exposed to the chemical. Acrylamide has been shown to bind to DNA and mouse protamine throughout the spermiogenic stages of the mouse, and it is believed to cause genetic damage [5] throughout this time. It has been shown that the use of acrylamide in rats is associated with increased prenatal mortality, mutagenicity, clastogenicity, endocrine-related malignancies, and male reproductive toxicity [6]. According to Yang et al. [7], acrylamide may be mutagenic to the Salmonella strains TA100 and TA98 when exposed to it. Mice given an intraperitoneal injection of acrylamide at a dose of $50 \mathrm{mg} / \mathrm{kg}$ exhibited an increase in the frequency of chromosomal abnormalities in their bone marrow after receiving the drug. The incidence of chromosomal abnormalities in lymphocytes from mice given intraperitoneal doses of acrylamide up to $125 \mathrm{mg} / \mathrm{kg}$ did not increase significantly when the acrylamide was delivered in this manner [8].

Male rats' reproductive systems are also harmed as a consequence of histological abnormalities in the seminiferous tubules that are produced by acrylamide. If acrylamide is breathed or absorbed via the skin, it may cause a burning sensation or a rash to appear. Symptoms of nervous system 
malfunction include excessive sweating, a sluggish body, and a shaky tongue [4]. Because of its high water solubility, acrylamide has the potential to be absorbed via the lungs, the digestive system, the placental barrier, and the skin. When acrylamide adducts in haemoglobin are measured, it may be determined how much acrylamide the general population is exposed to as a result of their occupation. A total of 41 workers at an acrylamide manufacturing plant exhibited neurotoxicity scores that were connected to the biomarker haemoglobin adducts, according to the findings. Haemoglobin adduct levels increased in a Chinese acrylamide manufacturing factory, indicating that the workers had received very high acrylamide exposure [9]. Multiple cases of acute acrylamide poisoning have been reported in Japan as a consequence of acrylamide contamination in the country's water supply. It was discovered by Igisu et al. [10] that an acrylamide concentration as high as $400 \mathrm{mg}$ acrylamide/L was detected in a well that had been contaminated by a grouting operation that was 2.5 metres deep. According to the findings, five individuals who had drunk poisoned drinking water had suffered symptoms such as truncal ataxia and disorientation, which were thought to be caused by acrylamide poisoning.

To obtain acrylamide into your system, you must either inhale polluted air or consume or drink anything that has been contaminated. Skin contact, mucous membranes in the lungs, and the digestive system are all possible routes of absorption for this substance. It will, however, be drained out of the body via the urine [11-13]. The availability of acrylamide in biological fluids and the dispersion of acrylamide throughout the body contribute to the facilitation of the acrylamide effect. A danger to workers and people exists due to the high degree of reactivity of acrylamide to proteins, despite the fact that it is rapidly metabolised and removed after exposure.

Volcanic soils are known to harbor several xenobioticsdegrading and biotransforming microorganisms [14-17], mostly hydrocarbon-degrading microorganisms. Microorganisms that have been reported as capable of utilizing acrylamide include the yeast Rhodotorula sp.[18], Pseudomonas sp.[19], the fungi Aspergillus oryzae [20], the bacterium Enterobacter aerogenes [21], Burkholderia sp. [22], Bacillus cereus [19](Shukor et al., 2009b, an Antarctic bacterium [19], Pseudomonas stutzeri [23] and Pseudomonas chlororaphis [24]. Here we describe the isolation and characterization of a novel acrylamide-degrading bacterial consortium strain from volcanic soil.

\section{MATERIALS AND METHODS}

All chemical reagents were generated in large quantities and utilised in the analysis in their unpurified forms, and all of the materials used in this study were of analytical grade. In all cases, unless otherwise noted, experiments were carried out in triplicate.

\section{Growth and maintenance of the acrylamide-degrading consortium}

Soil $(10 \mathrm{~g})$ was taken from $5 \mathrm{~cm}$ depth from the topsoil near Mount Marapi in West Sumatera, Indonesia in 2007. Soil $(1 \mathrm{~g})$ was mixed with sterile tap water $(10 \mathrm{~mL})$. Then $0.1 \mathrm{~mL}$ was added into $45 \mathrm{ml}$ of acrylamide enrichment medium in a $100 \mathrm{ml}$ volumetric flask and the culture was incubated at $25{ }^{\circ} \mathrm{C}$ on an incubator shaker (Certomat R, USA) at $150 \mathrm{rpm}$ for $48 \mathrm{~h}$. Minimal salt medium (MSM) was used to isolate the strains with constituents including $0.5 \mathrm{~g}$ acrylamide $\mathrm{g} / \mathrm{L}$, glucose $10 \mathrm{~g} / \mathrm{L}$, $\mathrm{MgSO}_{4} \cdot 7 \mathrm{H}_{2} \mathrm{O} 0.5 \mathrm{~g} / \mathrm{L}, \mathrm{KH}_{2} \mathrm{PO}_{4} 6.8 \mathrm{~g} / \mathrm{L}, \mathrm{FeSO}_{4} \cdot \mathrm{H}_{2} \mathrm{O} 0.005 \mathrm{~g} / \mathrm{L}$ and $10 \mathrm{~mL}$ of $\mathrm{H}_{3} \mathrm{BO}_{3} 0.05 \mathrm{~g} / \mathrm{mL}, \mathrm{ZnCl}_{2} 0.03 \mathrm{~g} / \mathrm{L}, \mathrm{CoCl}_{2} \cdot 6 \mathrm{H}_{2} \mathrm{O}$ $0.003 \mathrm{~g} / \mathrm{mL}, \mathrm{Cu}\left(\mathrm{CH}_{3} \mathrm{COO}\right)_{2} \cdot \mathrm{H}_{2} \mathrm{O} 0.01 \mathrm{~g} 0.002 \mathrm{~g}$ of $\mathrm{FeCl}_{2} \cdot 6 \mathrm{H}_{2} \mathrm{O}$
[3]. The $\mathrm{pH}$ of the media was adjusted to 7.5. For the sterilisation, PTFE syringe filters ( 0.45 micron) were used and acrylamide was used as the sole supply of nitrogen.

MSM acrylamide medium was used for serial transfer of acrylamide-degrading bacteria. Samples of one $\mathrm{mL}$ each were serially diluted in order to count microorganisms. It was cultured for three days at room temperature to generate pure cultures/consortiums from each of the $50 \mathrm{~mL}$ portions of each of the acceptable dilutions.

\section{Bacterial identification using Gram staining}

On a clean glass microscope slide, 2 loopful of sterilised distilled water were combined with $24 \mathrm{~h}$ incubated of individual pure culture of consortium A purified using single colony picked from agar plates and grown on nutrient broth. The culture was dispersed over a small area. The slide was then heated for a few s. In order to allow the dye to adhere to the bacteria's cell wall, it was then saturated with a few drops of crystal violet (the principal stain) and left for two min. A gentle stream of tap water was then used to rinse the slide thoroughly.

The slide was saturated with Gram's Iodine solution for one min, then washed with tap water. A few drops of 95 per cent ethyl alcohol (a decolorizing agent) were gently added to the smear and allowed to sit for $10 \mathrm{~s}$. Gram Safranin (final reagent) was counterstained for $1 \mathrm{~min}$ and washed with tap water to remove any remaining dye from the slide. It was then air-dried with bibulous paper before being seen using a light microscope (Olympus BX40.F4, Japan) at 1000X magnification with an oil immersion lens at 1000X (Cappuccino and Sherman, 2005).

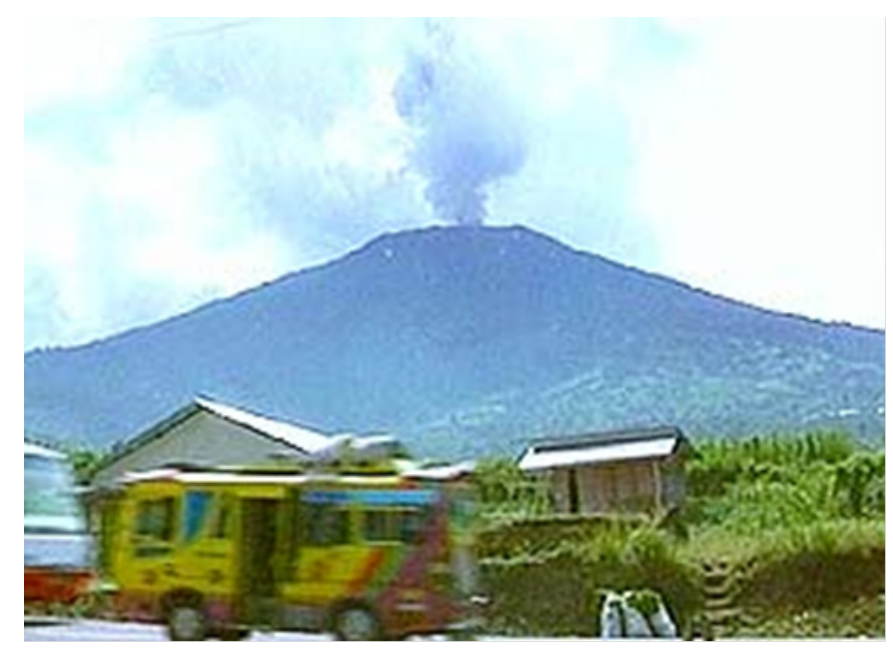

Fig. 1. Location of soil sampling near Mount Marapi, West Sumatra, Indonesia (pic courtesy of the Late Dr Neni Gusmanizar).

\section{Statistical Analysis}

All the information were evaluated utilizing Graphpad Prism (v 5.1). Values are means $\pm \mathrm{SD}$. One-way analysis of variance (with post hoc analysis by Tukey's test) or Student's t-test was used to equate among groups. P-value of $<0.05$ was considered as significant. 


\section{RESULTS}

Toxic xenobiotic Acrylamide (Fig. 2) is shown. Polyacrylamide is made from this component. Stabilizing tunnels and dams, as well as sewage-flocculating agents, and industrial adhesive applications are just some of the ways this polymer may be put to use (Rahim et al. 2012). Cows and fish have died in Sweden owing to acute acrylamide poisoning caused by environmental pollution [25]. The herbicide glyphosate has a dispersion agent of $20 \%$ to $30 \%$ polyacrylamide, and this might be a significant source of acrylamide pollution in soils and runoffs [26]. There have been reports of contamination from the acrylonitrileacrylamide industry with acrylamide levels of up to $1 \mathrm{~g} / \mathrm{L}$ [27].<smiles>C=CC(N)=O</smiles>

Fig 2. The structure of acrylamide.

\section{Acrylamide-degrading bacterial consortium}

Serial enrichment experiment yields a bacterial consortium consisting of two Gram-negative bacteria and 1 Gram-positive bacterium.

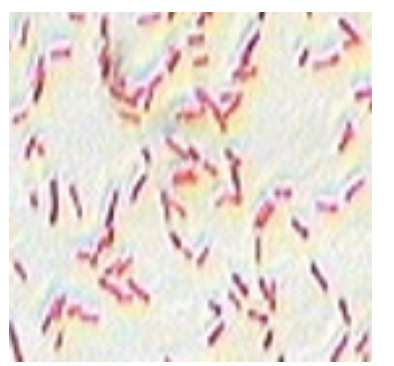

(a)

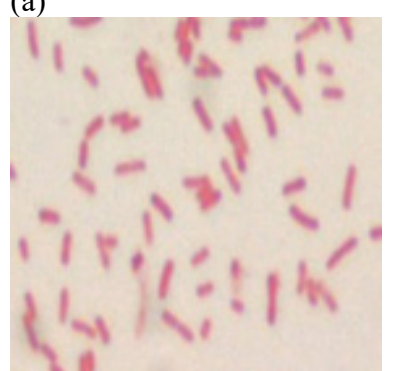

(b)

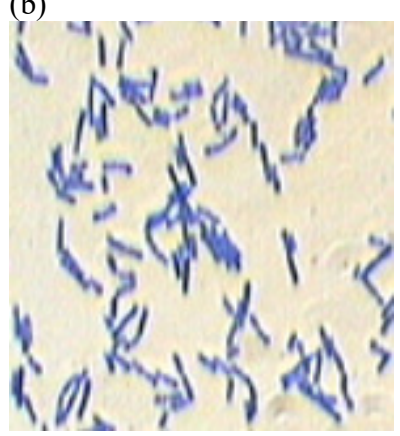

(c)

Fig. 3. Acrylamide-degrading bacterial consortium consisting of Gram negative bacteria ( $a$ and $b$ ) and a Gram positive bacterium (c) under oil emulsion 100x magnification.

\section{Effects of Initial pH and Temperature on Growth}

The consortium development was examined at room temperature in a $0.05 \mathrm{M}$ phosphate buffer to determine the impact of the initial $\mathrm{pH}$ ( $\mathrm{pH} 5.7$ to 8.5). After 48 hours of incubation, the growth rate was assessed. pH 6.5 to 8.0 was found to be optimal (Fig. 4). Outside of this range, growth slowed significantly. There was no significant difference in the development of acrylamide degrading bacteria between the two temperatures studied (Fig. 5). Temperatures lower than $30^{\circ} \mathrm{C}$ and greater than $35^{\circ} \mathrm{C}$ range saw a significant decline in growth.

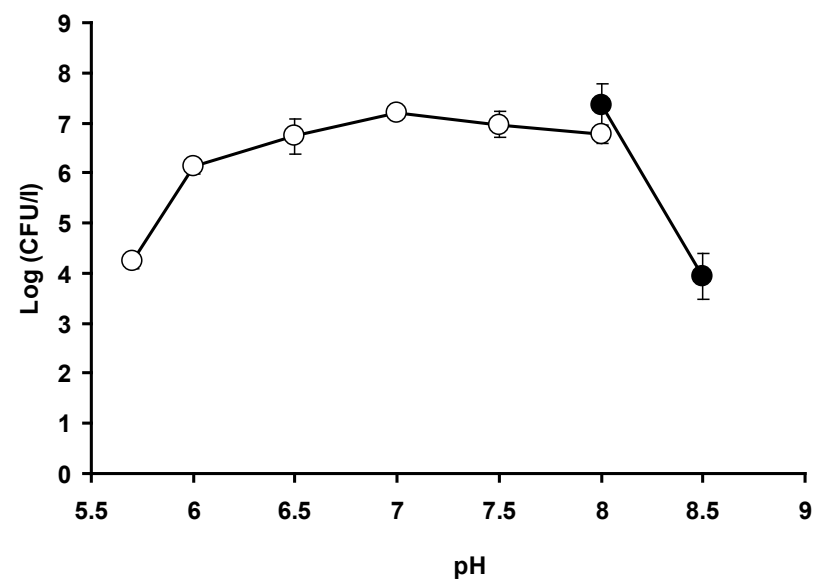

Fig. 3. Effect of $\mathrm{pH}$ on acrylamide degradation and growth of acrylamidedegrading consortium. The error bars represent the mean \pm standard deviation and $\mathrm{n}=3$.

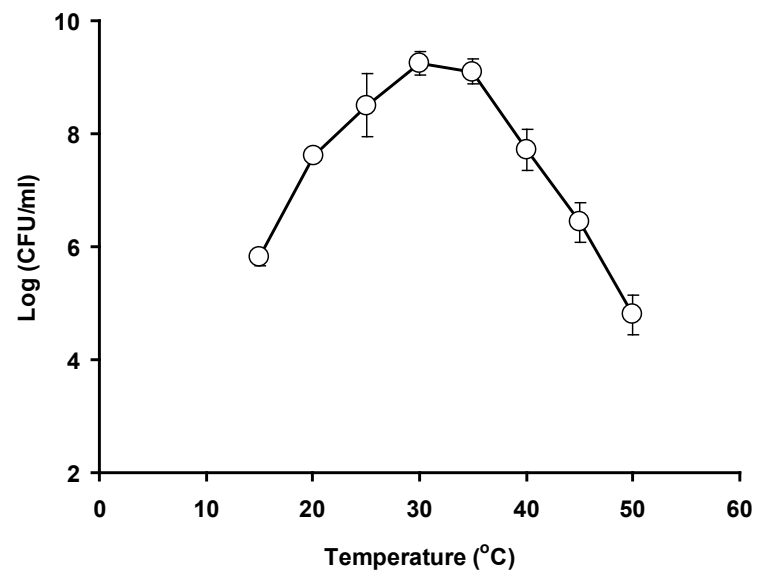

Fig. 4. Effect of temperature on acrylamide degradation and growth of acrylamide-degrading consortium. The error bars represent the mean \pm standard deviation and $\mathrm{n}=3$.

\section{Effects of Carbon Sources on Growth}

The effects of a 1.0 percent $(\mathrm{w} / \mathrm{v})$ starting concentration of several organic carbon sources such as fructose, glucose, lactose, maltose, mannitol, citric acid, and diesel on acrylamide breakdown were thoroughly investigated. The results showed that all carbon sources increased cellular development when 
compared to the control ( $\mathrm{p} 0.05)$, with glucose providing the most cellular growth after 72 hours of incubation (Fig. 5).

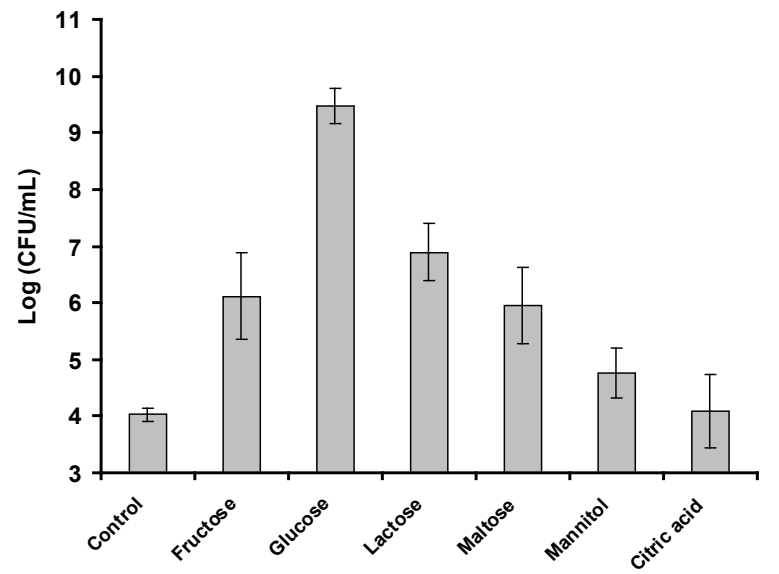

Fig. 5. The effect of carbon sources on degradation of $0.5 \mathrm{~g} / \mathrm{L}$ acrylamide and bacterial growth of acrylamide-degrading consortium. The error bars represent the mean \pm standard deviation and $n=3$.

\section{Effect of Acrylamide Concentration on Growth}

Acrylamide concentrations ranging from 200 to $1000 \mathrm{mg} / \mathrm{L}$ were employed in this study to determine the best acrylamide concentration for consortium growth. The maximum growth was achieved at the concentrations of between 300 and $500 \mathrm{mg} / \mathrm{L}$ of acrylamide, while growth was completely inhibited at $900 \mathrm{mg} / \mathrm{L}$ and above (Fig. 6).

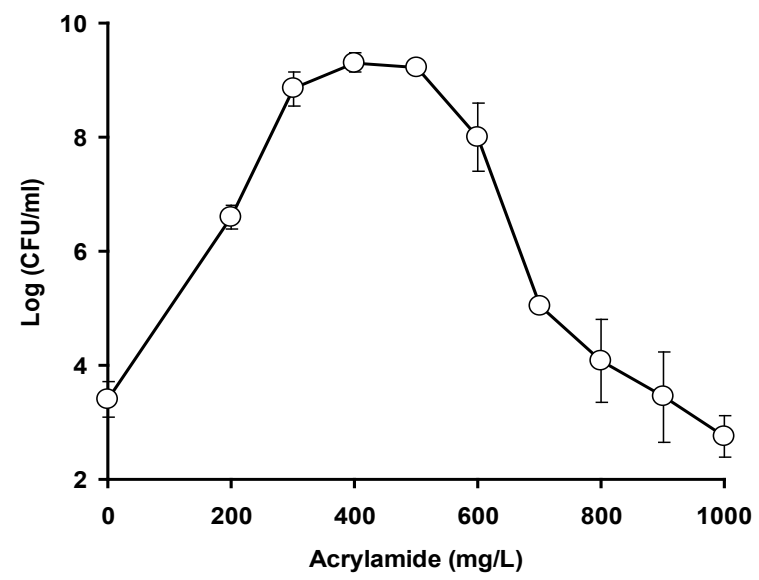

Fig. 6. Effect of different acrylamide concentrations on the growth of acrylamide-degrading consortium. The error bars represent the mean \pm standard deviation and $\mathrm{n}=3$.

\section{Effect of Different Amides on Growth}

Fig. 7 depicts the effect of several amides on the growth of this consortium. However, this consortium developed on acrylamide and acetamide but not on 2-chloroacetamide, methacrylamide, propionamide, or nicotinamide, which indicates that it is impervious to these compounds.

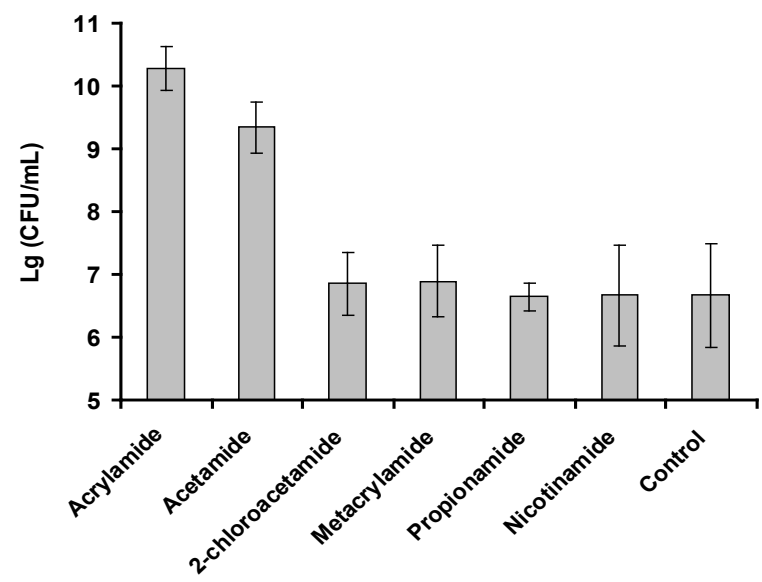

Fig. 7. Effect of different types of amides on acrylamide degradation by acrylamide-degrading consortium. The error bars represent the mean \pm standard deviation and $n=3$.

\section{Effect of Heavy Metals on the Growth and Degradation of} Acrylamide

The presence of heavy metals at the pollution site is a major limiting factor for bioremediation. This is owing to the fact that many bacteria cannot withstand high heavy metal concentrations and hence lose their ability to break down target molecules. A concentration of $2 \mathrm{ppm}$ of heavy metals (nickel $(\mathrm{Ni})$, copper $(\mathrm{Cu})$, lead $(\mathrm{Pb})$, cadmium $(\mathrm{Cd})$, chromium $(\mathrm{Cr})$, silver $(\mathrm{Ag})$, zinc $(\mathrm{Zn})$, and mercury $(\mathrm{Hg})$ ) was evaluated. The most severe inhibition was mercury followed by silver and copper causing 87,77 and $70 \%$ inhibition, respectively (Fig. 8).

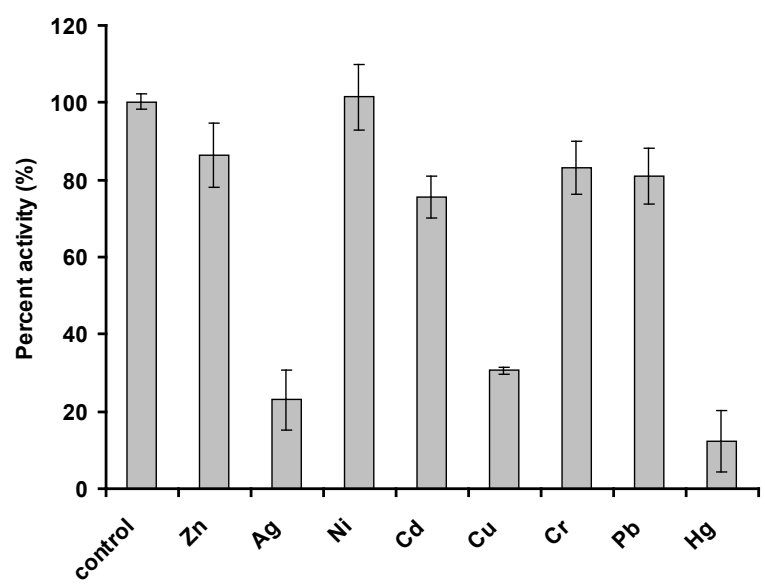

Fig. 8. The effect of heavy metals on acrylamide degradation by acrylamide-degrading consortium. The error bars represent the mean \pm standard deviation and $n=3$. 


\section{DISCUSSION}

The finding achieved in this investigation is consistent with various other publications about the influence of starting $\mathrm{pH}$. Several bacteria have reported an optimal $\mathrm{pH}$ of around 7.0 such as Pseudomonas sp. MCI3434 [28], for Rhodococcus sp. [29] and the yeast Rhodotorula sp. Rahim et al. [18] and Pseudonocardia thermophilic [30]. Tropical soils often have lower $\mathrm{pH}$ levels due to vigorous metabolic activity, such as the generation of organic acid and the production of carbon dioxide. As a result, in order to maximise cleanup, $\mathrm{pH}$-controlling chemicals must be provided to reach near to neutrality [31].

Temperature is a major component influencing biodegradation. The isolated bacteria grow optimally, as do other acrylamide-degrading microorganisms such as Pseudomonas chlororaphis, Pseudomonas aeruginosa and Pseudomonas stutzeri at 26,28 and $30^{\circ} \mathrm{C}$, respectively. A temperature of $30^{\circ} \mathrm{C}$ was reported as the best temperature for the growth of Rhodococcus rodochrous and Rhodococcus sp. [23,24,32] [33] and [29] whereas for Helicobacter pylori, found in the human gut, the optimum temperature is at $37^{\circ} \mathrm{C}$ [34]. Meanwhile, thermoactive bacteria require a greater temperature to develop well. Pseudonocardia thermophilic and Brevibacillus borstelensis BCS-1 for instance, grows optimally at $50^{\circ} \mathrm{C}$ and $55^{\circ} \mathrm{C}$ respectively $[30,35]$. Pseudomonas sp. strain DRYJ7 is the only documented acrylamide-degrading bacterium that degrades acrylamide optimally at $15 \mathrm{C}$ (cold-loving) [36].

Carbon sources are generally beneficial to bacterial growth on acrylamide when added to a low-salt medium with a minimum of salt. It is commonly acknowledged that glucose is the most optimal carbon source, and this consortium is no exception to this rule. Rhodococcus rhodochrous [37], Bacillus clausii and Burkholderia sp. [18], Pseudomonas sp. [36] and Bacillus cereus [3] require glucose at concentrations ranging from 0.5 to $2.0 \%$ $(\mathrm{w} / \mathrm{v})$. Other carbon sources have been reported. For example, soluble starch was used by Pseudonocardia thermophilic [30] to enhance the degradation of acrylamide while the eukaryote Aspergillus oryzae KBN1010 grows optimally on sucrose at 3\% (w/v) [20]. Salad oil was used by pseudomonas aeruginosa [38].

This work demonstrates that the acrylamide-degrading consortium can withstand acrylamide concentrations of up to 600 $\mathrm{mg} / \mathrm{L}$, with optimal growth occurring at $300 \mathrm{mg} / \mathrm{L}$. With nitrogen and carbon sources of nitrate and sucrose, respectively, the fungal strain $A$. oryzae was able to break down acrylamide concentrations of roughly $100 \mathrm{mg} / \mathrm{L}$, which is considered to be a low concentration [20]. Nevertheless, it seems likely that acrylamide breakdown is not a significant assimilatory mechanism in this bacterium. Pseudomonas stutzeri and Pseudomonas sp. strain DRYJ7 have been shown to have optimal acrylamide concentrations that sustain growth at 440 and 500 $\mathrm{mg} / \mathrm{L}$, respectively [19,37] while [39] reported that Ralstonia eutropha TDM-3 and Ralstonia eutropha AUM-01 can utilize up to $780-1990 \mathrm{mg} / \mathrm{L}$ acrylamide as the sole carbon and nitrogen source.

This work demonstrates that the acrylamide-degrading consortium was able to utilise basic aliphatic amides, as previously described by other investigations [40-47]. Instead of several short-chain amides, it can also degrade 2chloroacetamide, an amide compound that cannot be utilized by Pseudomonas sp. strain DRYJ7 [19] and Bacillus cereus strain DRY135 [48]. It is probable that acetamide and 2chloroacetamide, both of which contain carbon atoms, are the principal assimilatory routes for the breakdown of amides in this particular consortium. The fact that acrylamide and propionamide are both three-carbon atom compounds does not change the reality that acrylamide has more double bonds than propionamide, which results in a polyunsaturated (less stable) complex that is more easily attacked than propionamide $[49,50]$. The acrylamide-degrading consortium can therefore more easily employ amide compounds that are shorter or less stable.

Based on the findings of Bååth [51], heavy metals have a significant impact on the breakdown of acrylamide, with greater inhibition occurring in the presence of $\mathrm{Cd}, \mathrm{Cr}$, and $\mathrm{Hg}$ than other metals. At the moment, there is little information available in the literature about the influence of heavy metals on the breakdown of acrylamide. In light of the limited literature available on microbial tolerance to heavy metals, the findings of this study will be of great significance for bioremediation applications in the future.

\section{CONCLUSION}

A new acrylamide-degrading acrylamide-degrading consortium isolated from volcanic soil is reported. Growth was optimum in between pHs 6 and 8.0 and temperatures of between 30 and 35 ${ }^{\circ} \mathrm{C}$. Glucose was determined as the best carbon source and amides such as 2-chloroacetamide supported growth. Toxic heavy metals such as mercury, chromium, and cadmium, as well as other chemicals, impeded the development on acrylamide, according to the findings. The identification of the bacterial consortia, as well as the investigation of the metabolites of degradation and the kinetics of growth on acrylamide, are all planned for the future. A significant opportunity for bioremediation of acrylamide exists using the consortium, particularly in agricultural soils.

\section{REFERENCES}

1. Mottram, DS, Wedzicha BL, Dobson AT. Acrylamide is formed in the Maillard reaction. Nature. 2002;419:448-9.

2. Zamora R, Delgado RM, Hidalgo FJ. Strecker aldehydes and $\square$ keto acids, produced by carbonyl-amine reactions, contribute to the formation of acrylamide. Food Chem. 2011;128(2):465-70.

3. Shukor MY, Gusmanizar N, Azmi NA, Hamid M, Ramli J, Shamaan NA, et al. Isolation and characterization of an acrylamidedegrading Bacillus cereus. J Enviromental Biol. 2009;30(1):57-64.

4. Spencer P, Schaumburg HH. Nervous system degeneration produced by acrylamide monomer. Environ Health Perspect. 1975 Jun 1;11:129-33

5. Sega GA, Valdivia Alcota RP, Tancongco CP, Brimer PA. Acrylamide binding to the DNA and protamine of spermiogenic stages in the mouse and its relationship to genetic damage. Mutat Res Mutagen Relat Subj. 1989 Aug 1;216(4):221-30.

6. Tyl RW, Friedman MA. Effects of acrylamide on rodent reproductive performance. Reprod Toxicol. 2003 Jan 1;17(1):1-13

7. Yang H-J, Lee S-H, Jin Y, Choi J-H, Han C-H, Lee M-H Genotoxicity and toxicological effects of acrylamide on reproductive system in male rats. J Vet Sci. 2005 Jun;6(2):103-9.

8. Backer LC, Dearfield KL, Erexson GL, Campbell JA, WestbrookCollins B, Allen JW. The effects of acrylamide on mouse germ-line and somatic cell chromosomes. Environ Mol Mutagen. 1989;13(3):218-26.

9. Hagmar L, Törnqvist M, Nordander C, Rosén I, Bruze M, Kautiainen A, et al. Health effects of occupational exposure to acrylamide using hemoglobin adducts as biomarkers of internal dose. Scand J Work Environ Health. 2001;27(4):219-26.

10. Igisu H, Goto I, Kawamura Y, Kato M, Izumi K. Acrylamide encephaloneuropathy due to well water pollution. J Neurol Neurosurg Psychiatry. 1975;38(6):581-4.

11. Eikmann T, Herr C. How dangerous is actually acrylamide exposure for the population. Umweltmed Forsch Prax. 2002;7(6):307-8.

12. Pruser KN, Flynn NE. Acrylamide in health and disease. Front Biosci - Sch. 2011;3 S(1):41-51. 
13. Pennisi M, Malaguarnera G, Puglisi V, Vinciguerra L, Vacante M, Malaguarnera M. Neurotoxicity of acrylamide in exposed workers. Int J Environ Res Public Health. 2013;10(9):3843-54.

14. Meintanis C, Chalkou KI, Kormas KAr, Karagouni AD. Biodegradation of crude oil by thermophilic bacteria isolated from a volcano island. Biodegradation. 2006;17(2):105-11.

15. Djamaan A, Agustien A, Gemeidiya R, Jannah M, Asiska PD, Wangi QA. Isolation and identification of bioplastic producing bacteria from soil at the top of Marapi Volcano Mountain, West Sumatra, Indonesia. Pharma Chem. 2016;8(11):160-6.

16. Rakhmawati A, Wahyuni ET, Yuwono T. Lead uptake capacity of thermophilic bacteria Aeribacillus pallidus strains isolated from Merapi volcano, Indonesia. Korean J Microbiol. 2021;57(2):91-8.

17. Schubotz F, Lipp JS, Elvert M, Kasten S, Mollar XP, Zabel M, et al. Petroleum degradation and associated microbial signatures at the Chapopote asphalt volcano, Southern Gulf of Mexico. Geochim Cosmochim Acta. 2011;75(16):4377-98.

18. Rahim MBH, Syed MA, Shukor MY. Isolation and characterization of an acrylamide-degrading yeast Rhodotorula sp . strain $\mathrm{MBH} 23$ KCTC 11960BP. J Basic Microbiol. 2012;52(5):573-81.

19. Shukor MY, Gusmanizar N, Ramli J, Shamaan NA, Maccormack WP, Syed MA. Isolation and characterization of an acrylamidedegrading Antarctic bacterium. J Enviromental Biol. 2009;30(1):107-12.

20. Wakaizumi M, Yamamoto H, Fujimoto N, Ozeki K. Acrylamide degradation by filamentous fungi used in food and beverage industries. J Biosci Bioeng. 2009;108(5):391-3.

21. Buranasilp K, Charoenpanich J. Biodegradation of acrylamide by Enterobacter aerogenes isolated from wastewater in Thailand. J Environ Sci. 2011;23(3):396-403.

22. Syed M.A., Mahamood M., Shukor M.Y. SNA. Isolation and characterization of SDS-degrading Pseudomonas aeruginosa sp. strain D1. Aust J Basic Appl Sci. 2010;2010.

23. Wang C, Lee C. Denitri ${ }^{\circledR}$ cation with acrylamide by pure culture of bacteria isolated from acrylonitrile \pm butadiene \pm styrene resin manufactured wastewater treatment system. Chemosphere. $2001 ; 44$.

24. Ciskanik LM, Wilczek JM, Fallon RD, Petre D, Bacteriol J, Mayaux JF, et al. Purification and Characterization of an Enantioselective Amidase from Pseudomonas chlororaphis B23. Appl Environ Microbiol. 1995;61(3):998-1003.

25. Svensson K, Abramsson L, Becker W, Glynn A, Hellenäs K-E, Lind Y, et al. Dietary intake of acrylamide in Sweden. Food Chem Toxicol. 2003;41(11):1581-6.

26. Smith EA, Prues SL, Oehme FW. Environmental degradation of polyacrylamides. 1. Effects of artificial environmental conditions: Temperature, light, and $\mathrm{pH}$. Ecotoxicol Environ Saf. 1996;35(2):121-35.

27. Rogacheva SM, Ignatov OV. The respiratory activity of Rhodococcus rhodochrous M8 cells producing nitrile-hydrolyzing enzymes. Appl Biochem Microbiol. 2001;37(3):282-6.

28. Komeda H, Harada H, Washika S, Sakamoto T, Ueda M. S Stereoselective piperazine-2-tert-butylcarboxamide hydrolase from Pseudomonas azotoformans IAM 1603 is a novel L -amino acid amidase. Eurepean J Biochem. 2004;1475:1465-75.

29. Nawaz MS, Khan AA, Bhattacharayya D, Siitonen PH, Cerniglia CE. Physical biochemical and immunological characterization of a thermostble amidase from Klebsiella pneumonia NCTR 1. J Bacteriol. 1996;178:2397-401.

30. Egorova K, Trauthwein H, Verseck S. Purification and properties of an enantioselective and thermoactive amidase from the thermophilic actinomycete Pseudonocardia thermophila. Appl Microbiol Biotechnol. 2004;38-45.

31. Jonston JJ, Borden RC, Barlaz MA. Anaerobic biodegradation of alkylbenzenes and trichloroethylene in aquifer sediment down gradient of a sanitary landfill. J Contam Hydrol. 1996;23(4):26383.

32. Prabu CS, Thatheyus AJ. Biodegradation of acrylamide employing free and immobilized cells of Pseudomonas aeruginosa. Int Biodeterior Biodegrad. 2007;60:69-73.

33. Kotlova EK, Chestukhina (G.G, Astaurova OB, Leonova TE, Yanenko AS, Debabov VG. Isolation and primary characterization of an amidase from $<\mathrm{i}>$ Rhodococcus rhodochrous $<\mathrm{i} />$. Biochemistry. 1999;64:384-9.
34. Skouloubris S, A. L, H. R. Identification and characterization of an aliphatic amidase in Helicobacter pylori. J Mol Microbiol. 1997;25:989-98.

35. Baek S-H, Kim K-H, Yin C-R, Jeon CO, Im W-T, Kim K-K, et al. Isolation and characterization of bacteria capable of degrading phenol and reducing nitrate under low-oxygen conditions. Curr Microbiol. 2003;47(6):462-6.

36. Shukor MY, Ahmad SA, Nadzir MMM, Abdullah MP, Shamaan NA, Syed MA. Molybdate reduction by Pseudomonas sp . strain DRY2. J Appl Microbiol. 2010;108:2050-8.

37. Rogacheva SM, Ignatov OV. The Respiratory Activity of Rhodococcus rhodochrous M8 Cells Producing NitrileHydrolyzing Enzymes. Appl Biochem Microbiol. 2001;37(3):2826.

38. Shen S, Wan T, Hwang H. Biocatalysis and Agricultural Biotechnology Enhancement of degradation of acrylamide coupled with salad oil by Pseudomonas aeruginosa DS-4 using incubation periods. Biocatal Agric Biotechnol. 2012;1(2):110-4.

39. Cha M, Chambliss GH. Characterization of Acrylamidase Isolated from a Newly Isolated Acrylamide-Utilizing Bacterium , Ralstonia eutropha AUM-01. Curr Microbiol. 2011;671-8.

40. Buranasilp K, Charoenpanich J. Biodegradation of acrylamide by Enterobacter aerogenes isolated from wastewater in Thailand. J Environ Sci. 2011;23(3):396-403.

41. Bedade DK, Singhal RS. Biodegradation of acrylamide by a novel isolate, Cupriavidus oxalaticus ICTDB921: Identification and characterization of the acrylamidase produced. Bioresour Technol. 2018 Aug 1;261:122-32.

42. Aisami A, Gusmanizar N. Characterization of an acrylamidedegrading bacterium isolated from hydrocarbon sludge. Bioremediation Sci Technol Res. 2019 Dec 28;7(2):15-9.

43. Charoenpanich J, Tani A. Proteome analysis of acrylamide-induced proteins in a novel acrylamide-degrader Enterobacter aerogenes by 2D electrophoresis and MALDI-TOF-MS. Chiang Mai Univ J Nat Sci. 2014;13(1):11-22.

44. Wampler DA, Ensign SA. Photoheterotrophic metabolism of acrylamide by a newly isolated strain of Rhodopseudomonas palustris. Appl Environ Microbiol. 2005;71(10):5850-7.

45. Othman AR, Rahim MBHA. Modelling the Growth Inhibition Kinetics of Rhodotorula sp. strain MBH23 (KCTC 11960BP) on Acrylamide. Bioremediation Sci Technol Res. 2019 Dec 28;7(2):20-5

46. Yu F, Fu R, Xie Y, Chen W. Isolation and characterization of polyacrylamide-degrading bacteria from dewatered sludge. Int $\mathrm{J}$ Environ Res Public Health. 2015;12(4):4214-30.

47. Gusmanizar N, Shukor Y, Ramli J, Syed MA. Isolation and characterization of an acrylamide-degrading Burkholderia sp. strain DR.Y27. J Ris Kim. 2015 Feb 11;2(1):34

48. Mansur R, Gusmanizar N, Dahalan FA, Masdor NA, Ahmad SA, Shukor MS, et al. Isolation and characterization of a molybdenumreducing and amide-degrading Burkholderia cepacia strain neni-11 in soils from west Sumatera, Indonesia. IIOAB. 2016;7(1):28-40.

49. Markovetz AJ, Klug MJ, Forney FW. Oxidation of 1-Tetradecene by Pseudomonas aeruginosa. J Bacteriol. 1967 Apr 1;93(4):128993.

50. Hoenicke K, Gatermann R. Studies on the Stability of Acrylamide in Food During Storage. J AOAC Int. 2005 Jan 1;88:268-73.

51. Baath E. Effects of heavy metals in soil on microbial processes and populations (a review). Water Air Soil Pollut. 1989;47(3-4):33579. 